Members will note with satisfaction from the Audited Accounts and Balance Sheet circulated with this issue that the financial position of the Institute is sound, and they will endorse the vote of thanks passed by the Interim Committee to our Hon. Treasurer, Sir Humphrey Leggett, our Hon. Auditors, Messrs. Mann, Judd, Gordon \& Co., and to Mr. Leith of that firm for his constant supervision of our accounts.

HANNS VISCHER

Secretary-General and Acting Administrative Director

\title{
THE LATE PROFESSOR EUGEN MITTWOCH
}

Members of the Institute and students of Arabic and African Languages all over the world will have heard with deep regret of the death of this great scholar who passed away on November 8 th in London, where he had lived since 1935 . He began his studies in Berlin where he took his degree of Dr. Phil. in 1899 . After visiting Egypt, Palestine and Syria he became Privat-Dozent in Berlin in 1909 and Professor in I915. In 1920 he was appointed Director of the Seminar für Orientalische Sprachen and held that post until 1933 . Two years later, having been dismissed for being a Jew, he came to England and continued his studies quietly in London. He represented the Deutsche Morgenländische Gesellschaft on the Governing Body of the Institute until he left Germany, and during the last few months of his life he served as a member on our Interim Committee, besides giving us most valuable advice on the production of an Amharic Grammar. He contributed many articles to the Encyclopaedia of Islam, the Journal of the Seminar für Orientalische Sprachen and other scientific periodicals. $\mathrm{He}$ was the author and co-author of many 'standard works on Arabic literature and Amharic. Of the latter, the Amharic version of the Soirées de Carthage was perhaps the most important. He was deeply religious, a great friend, and above all a great scholar, and we of the London Office of our Institute shall always consider ourselves fortunate in having been allowed to work with this kind and modest man and great savant. 